\title{
Photosynthesis of Blueberry Leaves as Affected by Septoria Leaf Spot and Abiotic Leaf Damage
}

\author{
I. Roloff and H. Scherm, Department of Plant Pathology, and M. W. van Iersel, Department of Horticulture, Uni- \\ versity of Georgia, Athens 30602
}

\begin{abstract}
Roloff, I., Scherm, H., and van Iersel, M. W. 2004. Photosynthesis of blueberry leaves as affected by Septoria leaf spot and abiotic leaf damage. Plant Dis. 88:397-401.

Leaf spots caused by fungal pathogens or abiotic factors can be prevalent on southern blueberries after harvest during the summer and fall, yet little is known about how they affect physiological processes that determine yield potential for the following year. In this study, we measured $\mathrm{CO}_{2}$ assimilation and leaf conductance on field-grown blueberry plants affected by Septoria leaf spot (caused by Septoria albopunctata) or by edema-like abiotic leaf blotching. Net assimilation rate (NAR) on healthy leaves varied between 6.9 and $12.4 \mu \mathrm{mol} \mathrm{m} \mathrm{m}^{-2} \mathrm{~s}^{-1}$ across cultivars and measurement dates. Infection by $S$. albopunctata had a significant negative effect on photosynthesis, with NAR decreasing exponentially as disease severity increased $\left(R^{2} \geq 0.726, P<\right.$ 0.0001 ). NAR was reduced by approximately one-half at $20 \%$ disease severity, and values approached zero for leaves with $>50 \%$ necrotic leaf area. There was a positive, linear correlation between NAR and leaf conductance $\left(R^{2} \geq 0.622, P<0.0001\right)$, suggesting that the disease may have reduced photosynthesis via decreased $\mathrm{CO}_{2}$ diffusion into affected leaves. Estimates of virtual lesion size associated with infection by $S$. albopunctata ranged from 2.8 to 3.1, indicating that the leaf area in which photosynthesis was impaired was about three times as large as the area covered by necrosis. For leaves afflicted by edema-like damage, there also was a significant negative relationship between NAR and affected leaf area, but the scatter about the regression was more pronounced than in the NAR-disease severity relationships for $S$. albopunctata $\left(R^{2}=\right.$ $0.548, P<0.0001$ ). No significant correlation was observed between leaf conductance and affected area on these leaves $(P=0.145)$, and the virtual lesion size associated with abiotic damage was significantly smaller than that caused by $S$. albopunctata. Adequate carbohydrate supply during the fall is critical for optimal flower bud set in blueberry; therefore, these results document the potential for marked yield losses due to biotic and abiotic leaf spots.
\end{abstract}

Additional keywords: rabbiteye blueberry, southern highbush blueberry, Vaccinium ashei, $\mathrm{V}$. corymbosum

The blueberry industry in Georgia and other southeastern states has experienced considerable growth during the past 30 years due to improved cultivars and marketing opportunities $(13,22)$. This expansion is likely to continue in the near future, with consumer demand increasing due to the widely publicized health benefits of blueberry fruit $(12,20)$ and with producers seeking alternatives to traditional row crops which have become less profitable. Indeed, a recent producer survey in Geor-

Corresponding author: H. Scherm

E-mail: scherm@uga.edu

Funded in part by MBG Marketing, the Southern Region Small Fruit Consortium, the Office of International Agriculture at the University of Georgia, and the Institute for Phytopathology, University of Kiel, Germany (Prof. J.-A. Verreet).

Present address of I. Roloff: Institut für Phytopathologie, Universität Kiel, D-24118 Kiel, Germany.

Accepted for publication 1 December 2003.

Publication no. D-2004-0127-03R

(C) 2004 The American Phytopathological Society gia indicated that the area planted to blueberry may increase by as much as $35 \%$ within 5 years (23). In 2002, the statewide blueberry acreage totaled $>1,800$ ha, and utilized production was valued at $\$ 17.4$ million (2).

As blueberry acreage and production intensity have increased, disease problems have become more prevalent (23). Leaf spot diseases, in particular, have been a recent cause for concern in Georgia and neighboring states $(6,7,21)$. Leaf spots are most apparent after harvest during late summer and fall, and severe infection during this period can result in premature defoliation $(7,19)$. A recent field survey in Georgia (21) revealed a high incidence of leaf spots on cultivars of both rabbiteye blueberry (Vaccinium ashei) and southern highbush blueberry (V. corymbosum interspecific hybrids), the two blueberry species grown commercially in the state $(13,22)$. Septoria albopunctata (17) and Gloeosporium minus (16) were the pathogens most commonly associated with severe leaf spotting. However, leaf damage not associated with specific pathogens also was prevalent, especially on rabbiteye cultivars. Symptoms of this abiotic damage ranged from edema-like leaf blotching on both leaf surfaces to flecking and water soaking on the abaxial leaf surface; the latter symptom appeared to be associated with arthropod or mechanical injury, possibly blowing sand or mechanical harvest damage (21).

Regardless of its cause, severe leaf spotting and early loss of leaves could negatively impact initiation of flower buds during the fall due to reduced carbohydrate supply $(9,10)$, which, in turn, could result in decreased fruit yields in the following year. Indeed, when blueberry bushes were defoliated artificially (by clipping off leaves) in the fall, subsequent flower bud set or yield was reduced $(15,31)$. Although these results suggest that leaf spots may affect blueberry yields primarily via premature defoliation, it is important to consider that yield reductions are likely to occur even in the absence of defoliation if infected leaves contribute little to photosynthesis. For example, in a comparative study of 10 foliar pathosystems across a range of crops, reductions in leaf photosynthesis associated with a $10 \%$ disease severity level ranged from 20 to $50 \%$ (25). If reductions of a similar magnitude occur on blueberry leaves affected by leaf spots, yield losses are very likely even in the absence of defoliation, given the evidence for carbohydrate source limitation to fruit and vegetative growth in blueberry (27).

This study was undertaken to document and quantify the effects of leaf spots on photosynthesis of blueberry leaves in the field. The investigation focused on Septoria leaf spot, caused by $S$. albopunctata, and on edema-like abiotic leaf damage, presumed to be caused by over-irrigation following a prolonged period of drought during the summer.

\section{MATERIALS AND METHODS}

Field sites. The study was carried out in the fall of 2002 on field-grown, mature blueberry bushes at the University of Georgia Horticulture Farm near Watkinsville (Oconee County) and on a commercial farm near Homerville (Clinch County). Test plants at both sites had received no fungicide applications during the growing season. At the Watkinsville site, two cultivars of rabbiteye blueberry were studied: Premier, severely affected by Septoria leaf spot; and Climax, free from biotic leaf diseases but afflicted by edema- 
like leaf blotching. The latter symptom was characterized by reddish to darkbrown, irregularly shaped and slightly raised lesions that appeared initially as chlorotic areas. Microscopic examination and isolation attempts on standard microbiological media did not reveal any fungal or bacterial pathogens associated with these symptoms. Consistent with the etiology of edema development, symptoms appeared after a prolonged hot and dry period followed by excessive irrigation. At the Homerville site, measurements were carried out on Bluecrisp, a southern highbush blueberry cultivar severely affected by Septoria leaf spot.
Photosynthesis measurement and disease assessment. On two separate dates for each cultivar ( 8 and 12 September for Premier, 8 and 30 September for Climax, and 16 September and 2 October for Bluecrisp), net $\mathrm{CO}_{2}$ assimilation rate (NAR) and leaf conductance were measured on individual leaves using a portable photosynthesis monitoring system (CIRAS-1; PP Systems, Hitchin, Hertfordshire, UK). Plants were well watered at the time of measurement, and maximum air temperatures ranged from 26.2 to $32.2^{\circ} \mathrm{C}$. At least 20 mature leaves formed during the spring growth flush and located in the upper third of the canopy in arbitrarily chosen plants were selected per cultivar and date, such that a wide disease severity range (from 0 to $>50 \%$ necrotic leaf area) was represented. All measurements were taken within $1 \mathrm{~h}$ of solar noon at a photosynthetic photon flux density usually above $1,000 \mu \mathrm{mol} \mathrm{m} \mathrm{m}^{-2} \mathrm{~s}^{-1}$; light saturation in blueberry leaves occurs at photon flux densities between 500 and $800 \mu \mathrm{mol} \mathrm{m} \mathrm{m}^{-2} \mathrm{~s}^{-1}$ $(11,33)$. Following measurement, the area of the leaf that had been enclosed by the cuvette of the photosynthesis monitoring system was indicated with a marker pen, and leaves were detached and taken to the laboratory in a cooler. Disease severity of the $2.5-\mathrm{cm}^{2}$ photosynthesis measurement

Premier

Bluecrisp
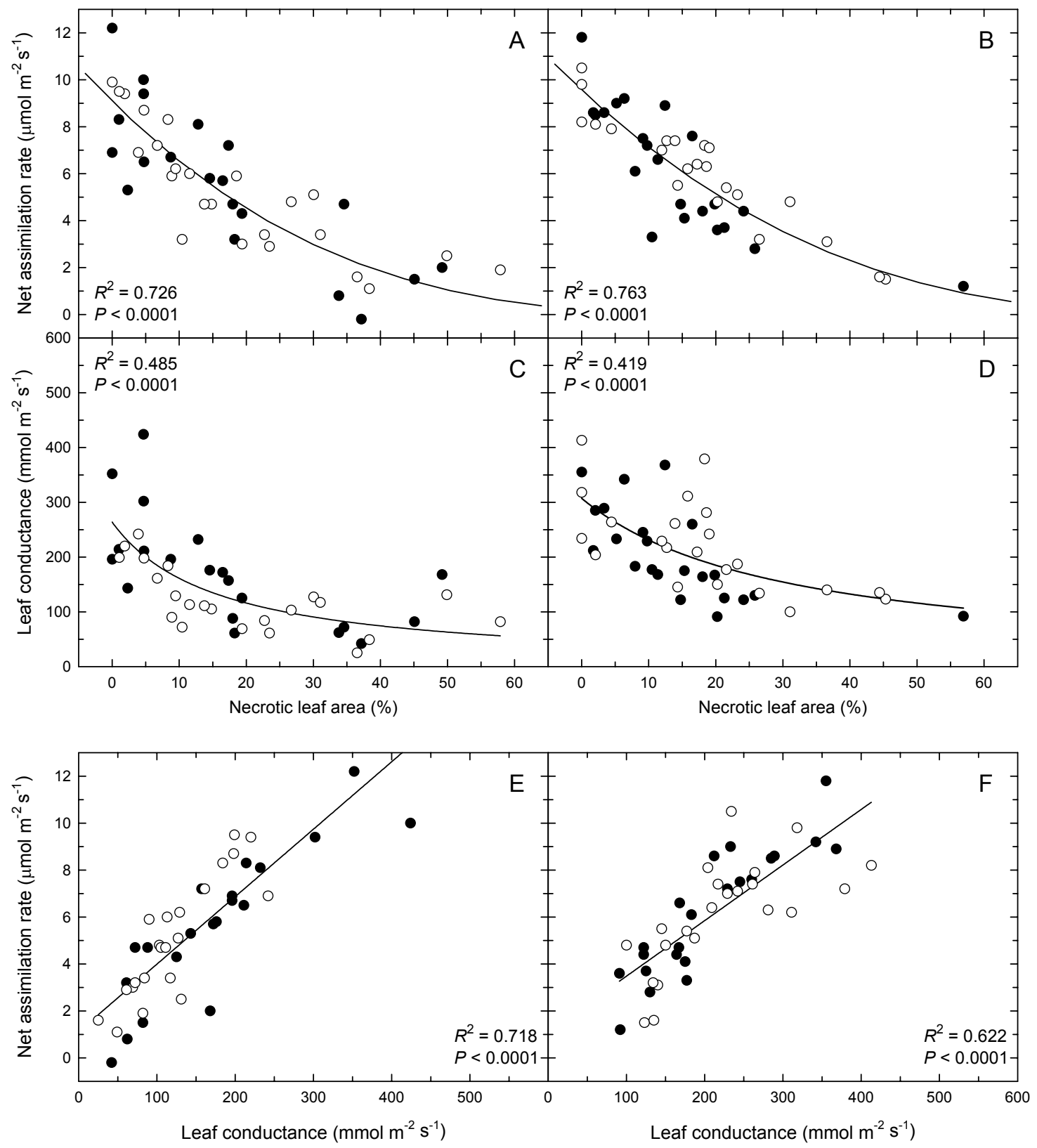

Fig. 1. $\mathbf{A}$ and $\mathbf{B}$, net $\mathrm{CO}_{2}$ assimilation rate and $\mathbf{C}$ and $\mathbf{D}$, leaf conductance in relation to Septoria leaf spot severity (caused by Septoria albopunctata) on Premier rabbiteye blueberry and Bluecrisp southern highbush blueberry. $\mathbf{E}$ and $\mathbf{F}$, relationship between net assimilation rate and leaf conductance for the two cultivars. Each data point consists of a single measurement on an individual leaf in the field. Open and solid symbols represent two separate trials, and solid lines correspond to the curves of best fit for pooled data from both trials. 
area was determined by computer image analysis (29) and expressed as percent necrotic leaf area.

Data analysis. Values of NAR and leaf conductance were plotted against disease severity and against each other, and linear and nonlinear regression analysis was applied to explore relationships among variables. Nonlinear regression analysis, fitted with PROC NLIN in the Statistical Analysis System (v. 8.02; SAS Institute, Cary, $\mathrm{NC})$, utilized the equation $p_{x}=p_{0}(1-$ $x / 100)^{\beta}$, where $p_{x}$ is NAR, $x$ is disease severity, and $p_{0}$ and $\beta$ are parameters that can be interpreted as NAR in the absence of disease and virtual lesion size, respectively (4). The virtual lesion size represents the ratio of the leaf area in which photosynthesis is reduced due to indirect effects of the disease and the leaf area that shows visible necrosis; it serves as a convenient parameter to express the physiological effects of disease on photosynthesis of the remaining green leaf tissue.

\section{RESULTS AND DISCUSSION}

NAR on healthy leaves (i.e., those without visible necrosis) varied between 6.9 and $12.4 \mu \mathrm{mol} \mathrm{m} \mathrm{m}^{-2} \mathrm{~s}^{-1}$ across cultivars and measurement dates (Fig. 1 and 2); the corresponding average values predicted by the zero intercept of the nonlinear regression ranged from 9.0 to $9.6 \mu \mathrm{mol} \mathrm{m}{ }^{-2} \mathrm{~s}^{-1}$ (Table $1)$. These values are similar to those reported previously for blueberry. For example, maximum NAR on healthy leaves of field-grown lowbush blueberry ( $V$. angustifolium) in Nova Scotia ranged from 9 to 10 $\mu \mathrm{mol} \mathrm{m} \mathrm{m}^{-2} \mathrm{~s}^{-1}$ (11). In a study on greenhouse-grown potted plants (33), values of NAR were comparable for Tifblue rabbiteye blueberry ( 7.8 to $9.0 \mu \mathrm{mol} \mathrm{m} \mathrm{m}^{-2} \mathrm{~s}^{-1}$ ) but noticeably lower for Sharpblue southern highbush blueberry $\left(4.5 \mu \mathrm{mol} \mathrm{m} \mathrm{m}^{-2} \mathrm{~s}^{-1}\right)$.

Infection by $S$. albopunctata had a significant negative effect on photosynthesis of Premier and Bluecrisp blueberry leaves: as disease severity increased, NAR decreased exponentially (Fig. 1A and B). Consistent for both cultivars, NAR was reduced by approximately one-half at $20 \%$ disease severity, and values approached zero for leaves with $>50 \%$ necrotic leaf area. Estimates of $p_{0}$ and $\beta$ obtained by nonlinear regression analysis were not significantly different between Premier and Bluecrisp, as shown by the overlap between means \pm asymptotic standard errors (Table 1); thus, the two cultivars, which are members of different blueberry species, responded similarly to disease-induced leaf necrosis. It should be noted, however, that leaf spots caused by $S$. albopunctata generally expand more rapidly on Bluecrisp (and other highly susceptible southern highbush blueberry cultivars) than on Premier (H. Scherm, unpublished); thus, a given level of leaf necrosis (and associated reductions in NAR) can occur with a smaller number of individual infections in the former cultivar than in the latter. This is an important consideration when developing leaf spot count-based decision thresholds for managing the disease across a range of blueberry cultivars and species.

In general, assimilation may be affected at two levels. If leaf conductance is decreased, $\mathrm{CO}_{2}$ diffusion into the leaf is slowed, thereby reducing photosynthesis
(32). Photosynthesis also may be reduced due to changes in leaf metabolism. Examples include increased respiration, inhibition of photosynthetic electron transfer, reductions in the amount or activity of photosynthetically active pigments or enzymes, and altered solute relations within affected host cells (24). In the present study, leaf conductance decreased expo-

\section{Climax}
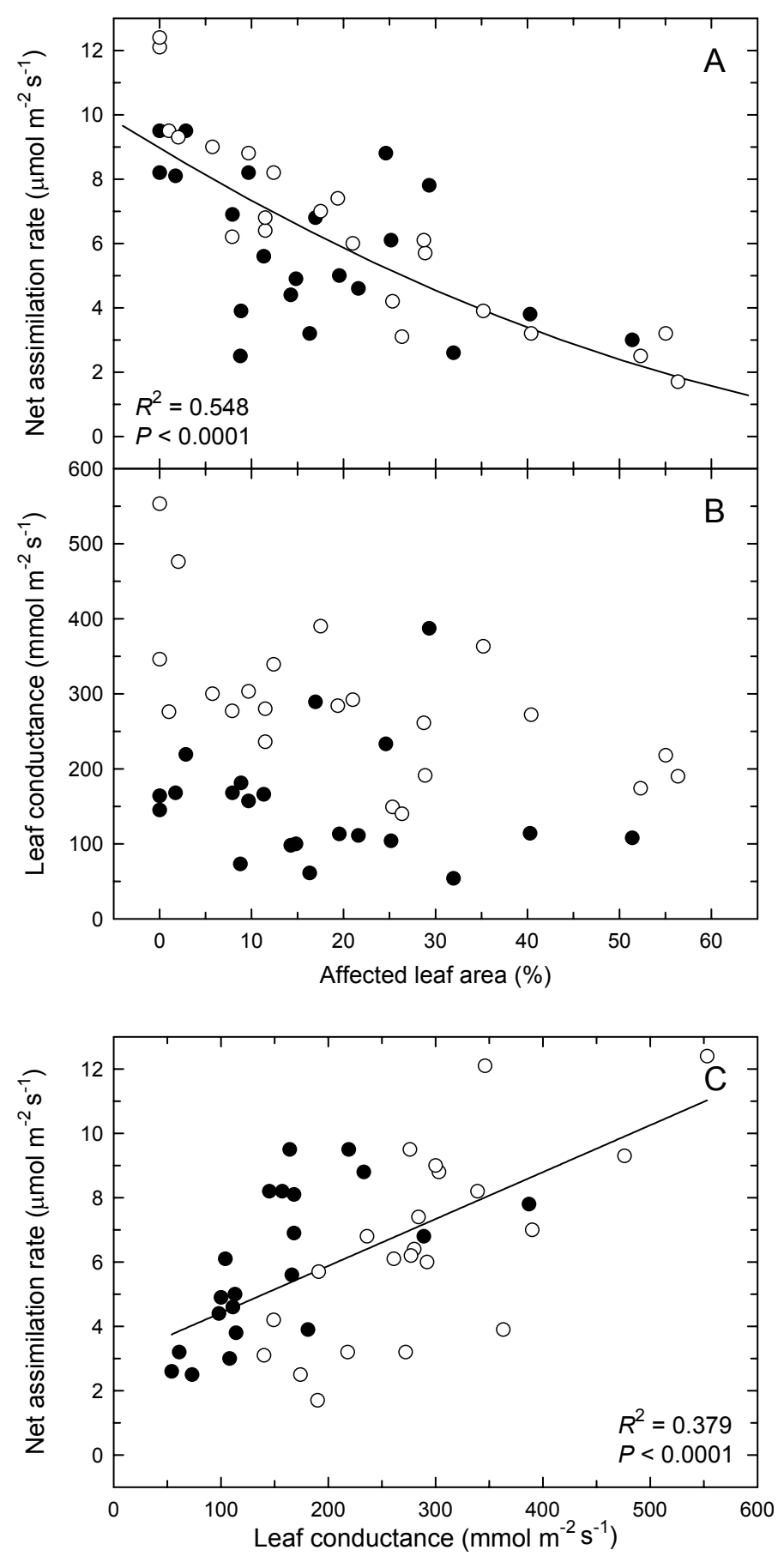

Fig. 2. $\mathbf{A}$, net $\mathrm{CO}_{2}$ assimilation rate and $\mathbf{B}$, leaf conductance in relation to severity of abiotic leaf damage on Climax rabbiteye blueberry. $\mathbf{C}$, relationship between net assimilation rate and leaf conductance. Each data point consists of a single measurement on an individual leaf in the field. Open and solid symbols represent two separate trials, and solid lines correspond to the curves of best fit for pooled data from both trials. There was no significant relationship between leaf conductance and necrotic leaf area $(P=0.145)$. 
nentially with increasing severity of Septoria leaf spot (Fig. 1C and D). Furthermore, there was a positive correlation between NAR and leaf conductance (Fig. 1E and F), suggesting that the disease may have reduced photosynthesis via decreased $\mathrm{CO}_{2}$ diffusion into affected leaves. Septoria leaf spot likely reduces leaf conductance by rendering stomata in necrotic areas nonfunctional, while any toxins that may diffuse into the surrounding leaf tissue may affect stomatal functioning in those areas as well. Several previous studies with other host-pathogen combinations also documented a close correlation between assimilation rate and leaf conductance $(14,24)$. In cherry leaves infected by the leaf spot pathogen Blumeriella jaapii, however, disease had the strongest negative effect on carboxylation, although leaf conductance also was reduced (18). More comprehensive gas exchange measurements are needed to determine the relative contribution of reduced $\mathrm{CO}_{2}$ diffusion versus changes in cell metabolism to reductions in photosynthesis in blueberry leaves infected by $S$. albopunctata.

The virtual lesion size associated with infection by $S$. albopunctata was $\beta=3.1 \pm$ 0.40 (standard error) for Premier and $2.8 \pm$ 0.29 for Bluecrisp (Table 1). Thus, the leaf area in which photosynthesis was impaired was about three times as large as the area covered by necrosis. The virtual lesion sizes obtained in this study are similar to values reported by Bastiaans (4) for fieldgrown rice infected by Pyricularia oryzae $(\beta=3.0 \pm 0.18)$. In other studies with necrotrophic pathogens, virtual lesion sizes ranged from 1.7 for Stagonospora nodorum on wheat to 11.0 for Cercospora arachidicola on peanut (30). The latter three pathogens all are known to produce host-specific toxins $(1,5,28)$, and diffusion of these compounds could be partly responsible for reductions in photosynthesis outside the necrotic leaf area. Toxin production has been reported for several species of Septoria $(3,8,26)$ but has yet to be demonstrated for Septoria albopunctata.

Lesions associated with edema-like damage on leaves of Climax were larger and more irregularly shaped than those caused by $S$. albopunctata on Premier and Bluecrisp, but overall severity of leaf dam- age was within the same range. There was a significant negative relationship between NAR and affected leaf area (Fig. 2A), but the scatter about the regression line was more pronounced than in the NAR-disease severity relationships for $S$. albopunctata on the other two cultivars (Fig. 1A and B). No significant correlation was observed between leaf conductance and necrosis on these leaves (Fig. 2B), suggesting that mechanisms other than reduced $\mathrm{CO}_{2}$ diffusion were responsible for the observed reductions in photosynthesis.

The virtual lesion size associated with leaf damage on Climax leaves $(\beta=1.9 \pm$ $0.33)$ was significantly smaller than that caused by $S$. albopunctata on the other two cultivars (Table 1). Although this result should be interpreted with caution because it is based on data from only one cultivar in one growing season, a smaller virtual lesion size would not be unexpected for leaves affected by abiotic damage because there are no pathogen structures or diffusible toxins that could extend from the symptomatic tissue to the surrounding green tissue. In a comparative study involving a range of foliar pathosystems, Shtienberg (25) also observed a proportionally greater reduction in photosynthesis beyond the symptomatic area in leaves infected by pathogens compared with those affected by abiotic damage.

Leaf spots caused by pathogenic fungi or abiotic factors can be prevalent and severe on blueberry in the southeastern United States (21). Recent field studies to document potential yield losses associated primarily with Septoria leaf spot have emphasized the importance of premature, disease-induced defoliation $(7,19)$, given prior evidence for reductions in flower bud initiation in the fall or fruit yield the following year on manually defoliated blueberry plants $(15,31)$. The present study, however, suggests that a sole focus on premature leaf loss may be inappropriate, given the significant reductions in photosynthesis that occur in affected leaves in the absence of defoliation. Indeed, average leaf spot severity values around $20 \%$, which reduced NAR by approximately one-half in the present study, are not uncommon on susceptible cultivars in Georgia during the fall (21). Given the potential

Table 1. Parameter estimates obtained from nonlinear regression analysis to calculate virtual lesion size on Premier rabbiteye blueberry and Bluecrisp southern highbush blueberry affected by Septoria leaf spot (caused by Septoria albopunctata), and on Climax rabbiteye blueberry affected by abiotic leaf damage

\begin{tabular}{lcccc}
\hline & \multicolumn{4}{c}{ Parameter $^{\mathbf{a}}$} \\
\cline { 2 - 5 } Cultivar & $\boldsymbol{p}_{\mathbf{0}}$ & $\boldsymbol{\beta}$ & $\boldsymbol{R}^{\mathbf{2}}$ & $\boldsymbol{P}$ \\
\hline Premier & $9.1 \pm 0.47$ & $3.1 \pm 0.40$ & 0.726 & $<0.0001$ \\
Bluecrisp & $9.6 \pm 0.39$ & $2.8 \pm 0.29$ & 0.763 & $<0.0001$ \\
Climax & $9.0 \pm 0.53$ & $1.9 \pm 0.33$ & 0.548 & $<0.0001$ \\
\hline
\end{tabular}

a Parameters were estimated using the equation $p_{x}=p_{0}(1-x / 100)^{\beta}$, where $p_{x}=$ net $\mathrm{CO}_{2}$ assimilation rate $\left(\mu \mathrm{mol} \mathrm{m} \mathrm{m}^{-2} \mathrm{~s}^{-1}\right), x=$ disease severity $(\%), p_{0}=$ net assimilation rate in the absence of disease $\left(\mu \mathrm{mol} \mathrm{m} \mathrm{m}^{-2} \mathrm{~s}^{-1}\right)$, and $\beta=$ virtual lesion size (4). Values are parameter estimates \pm asymptotic standard errors. for marked reductions in photosynthesis of blueberry leaves affected by biotic and abiotic leaf spots, together with the critical need for adequate carbohydrate supply during the fall for optimal flower bud set and yield $(9,10,27)$, further research focusing on quantitative yield loss relationships and practical treatment thresholds clearly is warranted.

\section{ACKNOWLEDGMENTS}

We thank A. Savelle, P. Ojiambo, and P. Brannen for assistance and useful discussion during various aspects of the study.

\section{LITERATURE CITED}

1. Abo-El-Dahab, M. K., Wasfy, E. H., ElGoorani, M. A., El-Kasheir, H. M., and Wagih, E. E. 1986. Cercosporin production by both peanut leaf spotting agents, Cercospora arachidicola and Cercosporidium personatum. Acta Phytopathol. Entomol. Hung. 21:273277.

2. Anonymous. 2003. Noncitrus Fruits and Nuts, 2002 Preliminary Summary. Fr Nt 1-3 (03), USDA-NASS, Washington, DC.

3. Balakrishna, H. K., and Rai, P. V. 1978. Biological and chemical properties of a toxic glycopeptide produced by Septoria lycopersici. Indian Phytopathol. 31:458-462.

4. Bastiaans, L. 1991. Ratio between virtual and visual lesion size as a measure to describe reduction in leaf photosynthesis of rice due to leaf blast. Phytopathology 81:611-615.

5. Bousquet, J. F., de Franqueville, H. B., Kollmann, A., and Fritz, R. 1980. Action of septorin, a phytotoxin synthesized by Septoria nodorum, on oxydative phosphorylation in mitochondria isolated from wheat coleoptiles. Can. J. Bot. 58:2575-2580.

6. Brannen, P. 2001. Leaf spots of blueberryHow to identify and control them. Pages 18-19 in: Proc. Southeast. Blueberry Conf. Savannah, GA. Department of Horticulture, University of Georgia, Tifton.

7. Cline, W. O. 2002. Blueberry bud set and yield following the use of fungicides for leaf spot control in North Carolina. Acta Hortic. 574:7174.

8. Cornish, P. S., Baker, G. R., and Murray, G. M. 1990. Physiological responses of wheat (Triticum aestivum) to infection with $M y$ cosphaerella graminicola causing Septoria tritici blotch. Aust. J. Agric. Res. 41:317-327.

9. Darnell, R. L. 1991. Photoperiod, carbon partitioning, and reproductive development in rabbiteye blueberry. J. Am. Soc. Hortic. Sci. 116:856-860.

10. Darnell, R. L., Stutte, G. W., Martin, G. C., Lang, G. A., and Early, J. D. 1992. Developmental physiology of rabbiteye blueberry. Hortic. Rev. 13:339-405.

11. Hicklenton, P. R., Reekie, J. Y., Gordon R. J., and Percival, D. C. 2000. Seasonal patterns of photosynthesis and stomatal conductance in lowbush blueberry plants managed in a twoyear production cycle. HortScience 35:55-59.

12. Joseph, J. A., Shukitt-Hale, B., Denisova, N. A., Bielinski, D., Martin, A., McEwen, J. J., and Bickford, P. C. 1999. Reversal of age-related declines in neuronal signal transduction, cognitive, and motor behavioral deficits with blueberry, spinach, or strawberry dietary supplementation. J. Neurosci. 19:8114-8121.

13. Krewer, G., and NeSmith, D. S. 2002. The Georgia blueberry industry: Its history, present state, and potential for development in the next decade. Acta Hortic. 574:101-106.

14. Lopes, D. B., and Berger, R. D. 2001. The effect of rust and anthracnose on the photosynthetic capacity of diseased bean leaves. Phytopathology 91:212-220. 
15. Lyrene, P. M. 1992. Early defoliation reduces flower bud counts on rabbiteye blueberry. HortScience 27:783-785.

16. Milholland, R. D. 1995. Gloeosporium leaf spot and stem canker. Page 16 in: Compendium of Blueberry and Cranberry Diseases. F. L. Caruso and D. C. Ramsdell, eds. American Phytopathological Society, St. Paul, MN.

17. Milholland, R. D. 1995. Septoria leaf spot and stem canker. Page 16 in: Compendium of Blueberry and Cranberry Diseases. F. L. Caruso and D. C. Ramsdell, eds. American Phytopathological Society, St. Paul, MN.

18. Niederleitner, S., and Knoppik, D. 1997. Effects of the cherry leaf spot pathogen Blumeriella jaapii on gas exchange before and after expression of symptoms on cherry leaves. Physiol. Mol. Plant Pathol. 51:145-153.

19. Ojiambo, P. S., Scherm, H., and Brannen, P. M. 2002. Septoria leaf spot intensity, defoliation, and yield loss relationships in southern blueberries. (Abstr.) Phytopathology 92:1025.

20. Prior, R. L., Cao, G., Martin, A., Sofic, E. McEwen, J., O'Brien, C., Lischner, N., Ehlenfeldt, M., Kalt, W., Krewer, G., and Mainland, C. M. 1998. Antioxidant capacity as influenced by total phenolic and anthocyanin content, maturity, and variety of Vaccinium species. J. Agric. Food Chem. 46:2686-2693.

21. Scherm, H., Brannen, P. M., Ojiambo, P. S.,
Savelle, A. T., Krewer, G., and Bruorton, M. D. 2003. Blueberry leaf spots: Epidemiology, yield losses, and control. Pages 57-66 in: Proc. Southeast. Blueberry Conf. Savannah, GA. Department of Horticulture, University of Georgia, Tifton.

22. Scherm, H., and Krewer, G. 2003. Blueberry production in Georgia: Historical overview and recent trends. Small Fruits Rev. 2(4):83-91.

23. Scherm, H., NeSmith, D. S., Horton, D. L., and Krewer, G. 2001. A survey of horticultural and pest management practices of the Georgia blueberry Industry. Small Fruits Rev. 1(4):17-28.

24. Scholes, J. D. 1992. Photosynthesis: Cellular and tissue aspects in diseased leaves. Pages 85106 in: Pest and Pathogens: Plant Responses to Foliar Attack. P. C. Ayers, ed. Bios, Oxford.

25. Shtienberg, D. 1992. Effects of foliar diseases on gas exchange processes: A comparative study. Phytopathology 82:760-765.

26. Song, H. D., Lim, S. M., and Clark, J. M., Jr. 1993. Purification and partial characterization of a host-specific pathotoxin from culture filtrates of Septoria glycines. Phytopathology 83:659-661.

27. Swain, P. A. W., and Darnell, R. L. 2002. Production systems influence source limitations to growth in 'Sharpblue' southern highbush blueberry. J. Am. Soc. Hortic. Sci. 127:409-414.
28. Tamari, K., and Kaji, J. 1954. Biochemical studies of the blast fungus (Pyricularia oryzae Cav.), the causative fungus of the blast disease of rice plants. I. Studies on the toxins produced by blast fungus. J. Agric. Chem. Soc. Jpn. 28:254-258.

29. Vale, F. X. R., Fernandes-Filho, E. I., Liberato, J. R., and Zambolim, L. 2001. Quant: A software to quantify plant disease severity. (Abstr.) Page 180 in: Proc. 8th Int. Workshop. Plant Dis. Epidemiol. Ouro Preto, Brazil.

30. van der Werf, W., Bastiaans, L., Rossing, W. A H., and Rabbinge, R. 1991. Modeling crop response to growth reducing factors. Pages 87 102 in: Proc. Symp. Biotic Stress of Barley in Arid and Semi-Arid Environments. Montana State University, Big Sky.

31. Williamson, J. G., and Miller, E. P. 2002. Early and mid-fall defoliation reduces flower bud number and yield of southern highbush blueberry. HortTechnology 12:214-216.

32. Wong, S. C., Cowan I. R., and Farquhar, G. D. 1979. Stomatal conductance correlates with photosynthetic capacity. Nature 282:424-426.

33. Wright, G. C., Patten, K. D., and Drew, M. C. 1993. Gas exchange and chlorophyll content of 'Tifblue' rabbiteye and 'Sharpblue' southern highbush blueberry exposed to salinity and supplementary calcium. J. Am. Soc. Hortix. Sci. 118:456-463. 